\title{
Venereal Diseases
}

\section{Extract from the Annual Report of the Chief Medical Officer of the Department of Health and Social Security for the year 1968}

THE venereal diseases continue to be a major cause of anxiety to all those concerned with the health of the community. The one cause for satisfaction is that in this country the spread of syphilis seems to be contained and, by the standards of most other countries in the world, the incidence of the disease in England and Wales is still very low. As in 1967, the returns from the clinics for 1968 show a significant increase in cases of gonorrhoea and in those of non-gonococcal urethritis in males. There was, also, an appreciable increase in the total numbers of patients attending the clinics with other conditions, which include other sexually communicable diseases, conditions of the genitals which prove to be non-infectious, and various anxieties for which patients, after investigation, are found to require only reassurance.

It should be understood that venereal disease clinics are committed to receive and investigate all patients who present themselves and that the majority attend of their own accord without preliminary examination or recommendation by their own doctors. The ever increasing numbers have thrown a considerable strain upon the staffs of clinics, especially in major cities and at seaports. One of the organizational difficulties is that numbers of patients are subject to considerable fluctuations at different times of the day, week and year. The problems of administration have occasionally become acute because of a sharp increase of new attenders following television programmes and newspaper articles on the subject of venereal diseases.

\section{Syphilis}

The traditional definition of infectious syphilis is retained to maintain continuity. It covers every infection believed to have been acquired within a year of the patient's first attendance and this includes the primary, secondary and early latent stages. In 1967 there were 1,732 of these cases reported from the clinics, of which 1,378 were in males and 354 in females showing a reduction of 4.8 per cent. from 1966 and

Report of the Department of Health and Social Security for the year ended December 31, 1968, p. 49, and Appendix C, p. 257. H.M.S.O., London. giving a male-female ratio of $3 \cdot 8: 1$ as compared with $3 \cdot 7: 1$ in 1966 . The corresponding total cases for 1968 were 1,826 , of which 1,444 were in males and 382 in females, an increase of 5.5 per cent as compared with 1967 and giving a male-female ratio of $3.8: 1$. Under the definition of infectious syphilis restricting the cases to those in the primary and secondary stages only, there were 1,321 cases in 1967 of which 1,075 were in men and 246 in women. The equivalent total for 1968 was 1,320 , of which 1,085 were in men and 235 in women, indicating no significant change in 1968 over 1967 and a male and female ratio of $4 \cdot 6: 1$ as compared with $4.4: 1$ in 1967.

The only conclusions to be drawn from these figures are that the situation remains essentially static and that control measures should be pursued with the hope that in due course they may prove to be more completely effective.

The number of cases of primary, secondary and early latent syphilis reported from ten urban areas in 1967 and 1968 are shown in Table I (opposite).

Cases from the Inner London area, always the major source of infection, increased from 784 in 1967 to 927 in 1968 . Both sexes showed appreciable increases, cases in men increasing from 679 to 778 and those in women from 105 to 149 . On Merseyside, on the other hand, there was a decrease in cases in both men and women, the former falling from 136 to 76 and the latter from 62 to 43 and the total therefore from 198 to 119 . Increases of varying degree were recorded at Manchester and Salford, Tyneside, Hull, Southampton and Bristol. Cases decreased at Birmingham, Leeds and Bradford, and at Sheffield.

Table II indicates the number of cases in which syphilis, seen in the primary and secondary stages, was believed to have been contracted in England and Wales or abroad. The proportions are similar to those of the previous year. Syphilis with its long incubation period was contracted abroad in $\mathbf{1 5 . 8}$ per cent. of cases as compared with 15.1 per cent. in 1967. It is important to make every effort to obtain contact information in 
T A B L E I Early syphilitic infections dealt with for the first time in ten sample areas, 1967-68

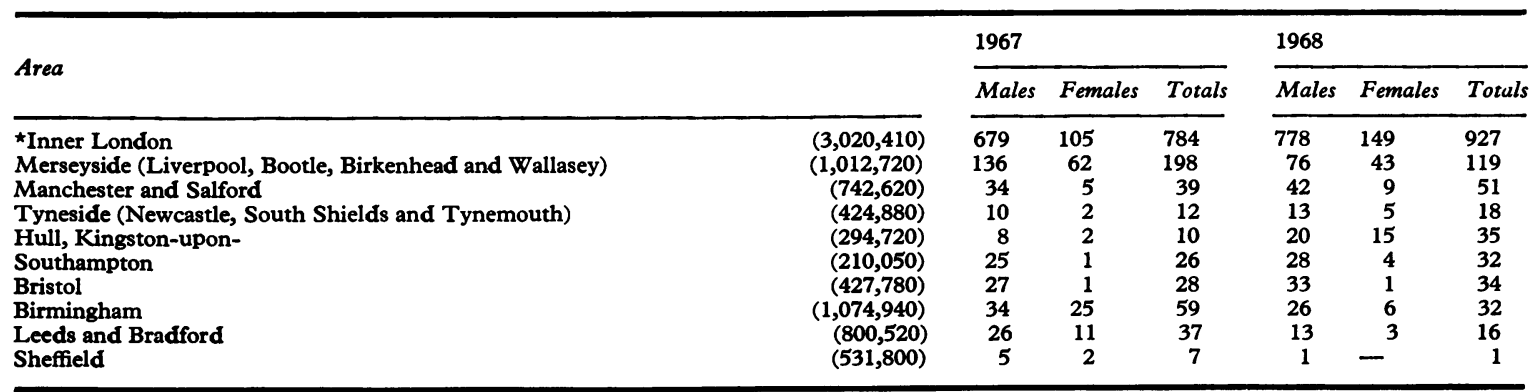

*The inner London Boroughs and the City of London.

Figures in brackets denote estimated populations at June 30, 1968.

TA BLE I I Infections contracted at home and abroad

\begin{tabular}{|c|c|c|c|c|}
\hline \multirow{2}{*}{ Infection } & \multicolumn{2}{|c|}{ Syphilis } & \multicolumn{2}{|c|}{ Gonorrhoea } \\
\hline & No. & Per cent. & No. & Per cent. \\
\hline $\begin{array}{l}\text { Contracted in the United } \\
\text { Kingdom } \\
\text { Contracted abroad } \\
\text { Not known }\end{array}$ & $\begin{array}{r}1,042 \\
208 \\
70\end{array}$ & $\begin{array}{r}78.9 \\
15.8 \\
5.3\end{array}$ & $\begin{array}{r}41,826 \\
1,724 \\
1,323\end{array}$ & $\begin{array}{r}93 \cdot 2 \\
3 \cdot 8 \\
3 \cdot 0\end{array}$ \\
\hline
\end{tabular}

this group, which should be passed on to the Department of Health and Social Security so that steps can be taken to inform the appropriate medical authorities in the countries of residence of the contacts.

Information obtained from the clinics regarding the ages of patients with primary and secondary syphilis is shown in Table VI. It relates to 1,307 patients who contributed a total of 1,320 infections. Of 1,077 males, 74 (6.9 per cent.) were under the age of 20 years and of 230 females 53 (23.0 per cent.) were in the same age group. The equivalent percentages for 1967 were $8 \cdot 6$ and 18.0 respectively.

The Co-operative Clinical Group of the Medical Society for the Study of Venereal Diseases has continued its yearly assessment of the relative incidence of primary and secondary syphilis among those who were born in this country and those from other countries. Details were obtained for 157 clinics in England and Wales relating to 1,195 cases of which 968 were in men and 227 in women, comprising 89.2 per cent. of the officially reported cases in men and 96.5 per cent. of those in women. Of the men, 65.0 per cent. were born in the United Kingdom, as compared with 60.9 per cent. in 1967, 9.0 per cent. in the Continent of Europe, 8.8 per cent. in the Wext Indies, 6.2 per cent. in Asia, and 4.2 per cent. in Eire; smaller numbers came from other countries. Of the women 79.7 per cent. were born in the United Kingdom, 8.4 per cent. in the West Indies, and 4.4 per cent. in Eire; smaller numbers were born in other countries. It must be realized that many of those born abroad are now resident in the United Kingdom, and are not recent immigrants. Some cases diagnosed are in visitors and foreign seamen, for whom diagnosis and treatment is provided under the Brussels Agreement.

During 1968 it was possible to take action regarding the contacts of 925 of the 1,085 cases in males suffering from primary and secondary syphilis and of 124 of the 235 cases in women. As a result of these measures 112 infected male contacts and 106 infected female contacts were brought under treatment. These figures of patients with infectious syphilis brought to the clinic as the result of contact tracing compare with 94 men and 87 women brought to the clinics by the same methods in 1967. This increase in numbers is encouraging and indicates the successful efforts of those working in this field who have thus brought to the clinics and rendered non-contagious 218 patients who might not otherwise have been correctly diagnosed. Cases of late syphilis show a minimal increase over the number for the preceding year. The details are shown in Table III. The difficulty of interpretation of these figures has been discussed in previous reports. Although the numbers of new cases of cardiovascular and neurosyphilis remain small the venereologist can still contribute useful clinical and serological advice to his colleagues in the differential diagnosis of cardiac and neurological problems. When once a definitive diagnosis of late syphilis is estab-

TABIE I I Late syphilis

\begin{tabular}{|c|c|c|c|c|}
\hline Type of late syphilis & Year & Males & Femul:s & Total \\
\hline Cardiovascular syphilis & $\begin{array}{l}1967 \\
1968\end{array}$ & $\begin{array}{l}95 \\
83\end{array}$ & $\begin{array}{l}41 \\
47\end{array}$ & $\begin{array}{l}136 \\
127\end{array}$ \\
\hline Neurosyphilis & $\begin{array}{l}1967 \\
1968\end{array}$ & $\begin{array}{l}156 \\
146\end{array}$ & $\begin{array}{l}69 \\
72\end{array}$ & $\begin{array}{l}225 \\
218\end{array}$ \\
\hline All other late or latent stages & $\begin{array}{l}1967 \\
1968\end{array}$ & $\begin{array}{l}714 \\
753\end{array}$ & $\begin{array}{l}580 \\
563\end{array}$ & $\begin{array}{l}1,294 \\
1,316\end{array}$ \\
\hline Totals, Late or Latent Stages & $\begin{array}{l}1967 \\
1968\end{array}$ & $\begin{array}{l}965 \\
982\end{array}$ & $\begin{array}{l}690 \\
679\end{array}$ & $\begin{array}{l}1,655 \\
1,661\end{array}$ \\
\hline
\end{tabular}


lished, he can also advise on the management and treatment of the patient and in particular draw attention to the importance of the examination and blood testing of the consort and children of those who are married.

The difficulty of distinguishing between syphilis and other treponemal diseases, such as yaws in immigrants, was also emphasized in last year's report. In 1967 it was noted that positive serological tests thought to be due to the non-venereal treponematoses were found in 903 cases. The equivalent figure for 1968 was slightly higher at 953 cases; but these variations are not significant.

Figures from the Registrar General's Annual Statistical Review show year by year the number of deaths reported from the major destructive effects of syphilis, namely general paralysis of the insane, tabes dorsalis, and syphilitic aneurysm of the aorta. Results over the years are shown in Appendix Table E. During 1968 deaths from general paralysis continued to show a decline. Deaths from tabes dorsalis declined also (in females). Deaths from aortic aneurysm have decreased in both sexes.

Congenital syphilis remains a small problem, but for this reason there should be no decrease in the efforts to prevent this type of infection, particularly in the ante-natal clinics. Cases identified in infants in the first year of life amounted to 14 in 1968 compared with 15 in 1967 (Appendix Table C). The death rate per 1,000 live births of infants under one year certified as due to congenital syphilis amounted to nil, as on several occsaions in recent years (Appendix Table D).

\section{Testing for syphilis in pregnancy}

The results of blood tests for syphilis in those groups of the population to which these tests are regularly applied, such as pregnant women, enable some estimate to be made of the prevalence of latent undiagnosed treponemal disease in various communities. Table IV shows the results of tests reported in 1968 from regional blood transfusion centres at which routine tests are performed for the regions concerned.

Table IV shows that the proportion of these patients with positive tests is very low indeed and Table V, which summarizes the results at these centres during the past 15 years, shows that the proportion has declined consistently during the last 6 years.

T A B L E V Results of serological tests in pregnant women, 1954-68

\begin{tabular}{|c|c|c|c|c|}
\hline \multirow{2}{*}{ Year } & \multicolumn{2}{|c|}{ Primiparae } & \multicolumn{2}{|c|}{ Multiparae } \\
\hline & No. & $\begin{array}{l}\text { Percentage } \\
\text { positive }\end{array}$ & No. & $\begin{array}{l}\text { Percentage } \\
\text { positive }\end{array}$ \\
\hline $\begin{array}{l}1954 \\
1955 \\
1956 \\
1957 \\
1958 \\
1959 \\
1960 \\
1961 \\
1962 \\
1963 \\
1964 \\
1965 \\
1966 \\
1967 \\
1968\end{array}$ & $\begin{array}{l}39,181 \\
41,392 \\
48,420 \\
49,914 \\
49,315 \\
56,962 \\
61,606 \\
67,294 \\
61,872 \\
68,347 \\
69,412 \\
72,623 \\
69,662 \\
70,859 \\
72,931\end{array}$ & $\begin{array}{l}0.23 \\
0.21 \\
0.28 \\
0.14 \\
0.13 \\
0.14 \\
0.08 \\
0.13 \\
0.11 \\
0.16 \\
0.12 \\
0.10 \\
0.07 \\
0.05 \\
0.05\end{array}$ & $\begin{array}{l}47,941 \\
40,712 \\
40,295 \\
43,730 \\
40,765 \\
46,531 \\
46,349 \\
49,583 \\
48,433 \\
57,774 \\
61,362 \\
61,287 \\
59,043 \\
58,782 \\
65,744\end{array}$ & $\begin{array}{l}0.32 \\
0.43 \\
0.35 \\
0.29 \\
0.23 \\
0.16 \\
0.14 \\
0.27 \\
0.19 \\
0.22 \\
0.20 \\
0.13 \\
0.11 \\
0.08 \\
0.06\end{array}$ \\
\hline
\end{tabular}

\section{Gonorrhoea}

The continual failure to control this infection is now one of the major public health problems in the field of the communicable diseases of known aetiology. The fact that the disease is readily transmitted by genital contact after a short incubation period, that males are contagious before symptoms develop, and that many females remain symptom-free after infection, means that gonorrhoea always spreads rapidly in a promiscuous community. Contact tracing must also be rapid to be effective, and those working in this highly skilled field must not only attempt to identify the contacts with the co-operation of patients, but also search for, find, and finally persuade them to attend a clinic for diagnosis and treatment. Last year's report indicated higher figures for 1967 at 41,289

TABLE IV Syphilis in pregnancy, 1968

\begin{tabular}{|c|c|c|c|c|c|c|c|c|c|}
\hline \multirow{3}{*}{ Centre } & \multicolumn{3}{|c|}{ No. of antenatal patients } & \multicolumn{6}{|c|}{ Positive syphilis tests } \\
\hline & \multirow[t]{2}{*}{ Primiparae } & \multirow[t]{2}{*}{ Multiparae } & \multirow[t]{2}{*}{ Parity not known } & \multicolumn{2}{|c|}{ Primiparae } & \multicolumn{2}{|c|}{ Multiparae } & \multicolumn{2}{|c|}{ Parity not known } \\
\hline & & & & No. & Per cent. & No. & Per cent. & No. & Per cent. \\
\hline $\begin{array}{l}\text { Cambridge } \\
\text { Leeds } \\
\text { Liverpool } \\
\text { Oxford } \\
\text { Plymouth } \\
\text { Sheffield }\end{array}$ & $\begin{array}{r}9,066 \\
13,433 \\
20,077 \\
3,614 \\
2,589 \\
24,152\end{array}$ & $\begin{array}{r}11,177 \\
7,933 \\
24,279 \\
4,792 \\
3,040 \\
14,523\end{array}$ & $\begin{array}{l}623 \\
1,140 \\
- \\
1,724 \\
-\end{array}$ & $\begin{array}{r}12 \\
4 \\
2 \\
2 \\
10 \\
7\end{array}$ & $\begin{array}{l}0.132 \\
0.029 \\
0.009 \\
0.055 \\
0.424 \\
0.028\end{array}$ & $\begin{array}{r}13 \\
6 \\
10 \\
10 \\
3\end{array}$ & $\begin{array}{l}0.116 \\
0.075 \\
0.041 \\
0.328 \\
0.020\end{array}$ & $\begin{array}{l}- \\
z \\
z\end{array}$ & $\begin{array}{l}- \\
z \\
-\end{array}$ \\
\hline
\end{tabular}


cases, an increase of 11.6 per cent. on 1966 after they had been fairly stable for the previous few years (albeit at a high level). In 1968 there has been a further significant increase to 44,962 cases, which is an increase of 7.5 per cent. Cases in adult males rose from 30,630 in 1967 to 32,586 in 1968; those in adult females from 11,081 to 12,287 . The male : female ratio was approximately 2.7 as compared with 2.8 in 1967. This may indicate that an increasing number of women, who would not otherwise attend because of the absence of symptoms, are now being brought to these clinics through the contact tracing system. The total of 44,962 cases includes 54 of vulvovaginitis, as compared with 77 in 1967, and 35 of gonococcal ophthalmia of the newborn as compared with 41 in 1967. The returns from the clinics showed that the 44,873 infections acquired by patients from the age of puberty involved 40,772 individuals, indicating that multiple infections continue to add significantly to the total cases in any one year.

The ages of patients suffering from gonorrhoea are shown in Table VI. The proportion of patients with gonorrhoea under the age of 20 was 15.6 per cent., as compared with 15.1 per cent. in 1967 . There were 71 boys and 219 girls under the age of 16 who presented with infection as compared with 36 boys and 179 girls in 1967. The number of boys aged 16 to 19 was 2,938 as compared with 2,653 in 1967, and the number of girls was 3,126 as compared with 2,850 in 1967. In the age group of 19 years and under, the total for boys at 3,009 was outnumbered by the girls at 3,345.

In general the pattern of distribution in these younger age groups is similar to that of recent years, but the increase over 1967 was 11.1 per cent. as compared with the overall increase of 7.5 per cent.

The Co-operative Clinical Group conducted a further study into the countries of origin of patients suffering from gonorrhoea. Details were collected from 157 clinics in England and Wales relating to 38,325 cases, or 85.2 per cent. of the total officially reported in the Annual Returns. Of 27,846 men suffering from gonorrhoea, 57.8 per cent. were born in the United Kingdom as compared with 56.4 per cent. in the similar study in 1967.17 .2 per cent. were born in the West Indies, 6.7 per cent. in Asia, 4.7 per cent. in Eire, 4.3 per cent. on the Continent of Europe, and 3.8 per cent. in Mediterranean countries; smaller numbers came from other countries. Of 10,479 females, 82.7 per cent. were born in the United Kingdom as compared with 82.1 per cent. in 1967 , 6.9 per cent. in the West Indies, and 4.3 per cent. in Eire, with smaller numbers from other countries.

At the clinics 'contact slips' were issued to 23,864 patients (21,114 men and 2,750 women) suffering from gonorrhoea. As the result of this and other measures, the attendance was secured of 7,271 infected contacts (1,520 men and 5,751 women). These figures compare with 1,227 men and 5,444 women in 1967, and show a further improvement in the figures allowing for the increase of total cases from the previous year.

\section{Prostitutes in Holloway prison}

The number of prostitutes admitted to H.M. Prison, Holloway, during 1968 was 495 as compared with 516 in 1967. The total number of these admissions also decreased from 866 to 749 . Of the 495, 467 submitted to examination and of these one was found to be suffering from primary syphilis, four from secondary syphilis, and 82 from gonorrhoea. Seven of the latter were treated for the disease on more than one occasion. 94 of the prostitutes were aged between 15 and 20 years and 91 submitted to examination and tests; one of these was suffering from infectious syphilis and 31 from gonorrhoea.

\section{Other venereal diseases}

Cases of non-gonococcal urethritis in men were first recorded in a separate category in 1951 and since then the number of reported cases has increased each year. The same trend continued in 1968 when cases numbered 35,721 as compared with 32,318 in 1967. There were 298 of these cases complicated by arthritis as compared with 357 in 1967. The corresponding condition in women is not a clear-cut clinical entity and is included among 'other conditions requiring treatment within the centre', the number

T A B L E V I Ages of patients suffering from early syphilis and gonorrhoea, by sex

\begin{tabular}{|c|c|c|c|c|c|c|c|c|}
\hline \multirow{2}{*}{ Age (yrs) } & \multicolumn{4}{|c|}{ Primary and secondary syphilis } & \multicolumn{4}{|c|}{ Gonorrhoea } \\
\hline & Males & Females & Total No. & Per cent. & Males & Females & Total No. & Per cent. \\
\hline $\begin{array}{l}\text { Under } 16 \\
16 \text { and } 17 \\
18 \text { and } 19 \\
20-24 \\
25 \text { and over }\end{array}$ & $\begin{array}{r}3 \\
16 \\
55 \\
278 \\
725\end{array}$ & $\begin{array}{r}2 \\
18 \\
33 \\
67 \\
110\end{array}$ & $\begin{array}{r}5 \\
34 \\
88 \\
345 \\
835\end{array}$ & $\begin{array}{r}0.4 \\
2 \cdot 6 \\
6 \cdot 7 \\
26 \cdot 4 \\
63 \cdot 9\end{array}$ & $\begin{array}{r}71 \\
629 \\
2,309 \\
9,336 \\
17,066\end{array}$ & $\begin{array}{r}219 \\
1,131 \\
1,995 \\
4,082 \\
3,934\end{array}$ & $\begin{array}{r}290 \\
1,760 \\
4,304 \\
13,418 \\
21,000\end{array}$ & $\begin{array}{r}0.7 \\
4 \cdot 3 \\
10 \cdot 6 \\
32 \cdot 9 \\
51 \cdot 5\end{array}$ \\
\hline Totals & 1,077 & 230 & 1,307 & $100 \cdot 0$ & 29,411 & 11,361 & 40,772 & $100 \cdot 0$ \\
\hline
\end{tabular}


of which in females increased from 28,417 in 1967 to 33,658 in 1968 .

The other venereal diseases continue to be seldom met except in ports or cities with large immigrant populations. There were 53 cases of chancroid compared with 64 in 1967, 55 cases of lymphogranuloma venereum as compared with 58 , and eleven cases of granuloma inguinale as compared with one in the preceding year (Appendix Table A).

\section{Other conditions seen at the clinics}

Details are shown in Appendix Table A. In 1968 there were 61,667 cases of other conditions requiring treatment as compared with 53,754 in 1967 , and 49,208 cases of other conditions requiring no treatment at the clinics as compared with 44,706 in 1967.

\section{The present position}

The Report for 1967 concluded that syphilis could be controlled even in a society in which premarital and extramarital intercourse are regarded by many as the norm. The figures for 1968 give no reason for changing that conclusion, but it has to be remembered that under present conditions the measure of control which exists can be maintained only by unremitting effort on the part of those concerned with the problem. The reasons why gonorrhoea has defied all efforts at control have been discussed in successive reports and unfortunately the factors described are still operative. More basic research on the gonococcus is needed before progress can be made. The communicable disease usually called non-gonococcal or 'non-specific' genital infection is also a most serious problem at the present time. Research over the years has failed to establish the causative agent and there are now plans to intensify these investigations. The first requirement for effective control of the various sexually transmitted diseases is the provision of adequate facilities for diagnosis and treatment with good medical and nursing standards. There can be no doubt that these exist in spite of the stresses and strains on staff already mentioned. It is also important that the public should be fully informed of the facilities available, and this is a matter which could be improved in some areas. What more can be done? Some have pinned hopes on the ultimate discovery of prophylactic methods including effective vaccination, but there seems no prospect of measures of this kind being available in the early future. There remain then contact tracing and health education.

The National Health Service (Venereal Diseases) Regulations, 1968, came into force in December of that year and had the effect of removing certain difficulties in communicating confidential information to those concerned with contact tracing. At the same time a memorandum giving detailed advice on the procedure for contact tracing was sent from the Department of Health and Social Security to all Regional Hospital Boards, Hospital Management Committees, Boards of Governors, and Local Health Authorities. These organizations were asked to cooperate fully in this activity (HM(68)84). The effect of this exhortation remains to be seen, but in the past there has certainly been unevenness in the degree of participation in these procedures. During the last few years some venereologists and some Medical Officers of Health have undertaken this important task with energy and enthusiasm and with gratifying success in some areas: others have taken little interest or have played only a perfunctory part in an undertaking which requires to be nation-wide if it is to have lasting success.

Health education relating to the sexually transmitted diseases is clearly only part of instruction in the relationship between the sexes, which should include the place occupied by love and marriage in a full life as well as the mental and physical dangers inherent in promiscuous behaviour. In the past this kind of instruction has been variable and uncoordinated and in many cases completely lacking. Presumably efforts should be concentrated particularly on young people who are now enjoying greater advantages in general education than their predecessors and for the most part do not lack the capacity for independent thought. The problem is the direct concern of the educational authorities, social services, and religious organizations, but it is a matter in which doctors and nurses should be prepared to participate. The combined efforts of health education officers and consultant venereologists have organized notably successful courses of instruction in certain parts of the country, such as Sheffield and Wigan, but it is clearly desirable that there should be a common plan based on study of the available methods. A joint Working Party from the Departments of Education and Science and of Health and Social Security has made a start by preparing notes for the guidance of teachers giving this kind of instruction when dealing with communicable diseases and in planning a film-strip for general distribution. The newly-formed Health Education Council is well aware of the problem and has already taken preliminary steps to review the visual aids to the type of instruction at present available and to prepare new material if indicated. No doubt more consultant venereologists and their staffs will be asked to act as local advisors and, if necessary, to lecture to pupils, students, teachers, and even parents, if specialized instruction in this subject appears to be expedient. This method of influencing sexual behaviour has not 
been given a genuine trial in this country although many believe that it has an important part to play in adding to human happiness and controlling the spread of venereal infection. In any case, young people are entitled to sensible instruction in these matters and they should know the dangers which result from promiscuous behaviour.

It is to be hoped, also, that general practitioners, standing as they do in close relationship to the families they serve, will be ready to provide instruction and advice in these intimate matters. It seems likely that they refer most of the patients suspected of venereal infection to appropriate clinics, but there are, of course, circumstances when the family doctor feels that the interests of the patient are best served by himself undertaking treatment. $\mathrm{He}$ is then involved in responsibility for accurate diagnosis, treatment, follow-up, and contact tracing. A booklet prepared by the Standing Medical Advisory Committee to the Ministry of Health, entitled 'Venereal Disease Service', was sent to all family doctors in 1962 and gave detailed suggestions for methods of handling most aspects of this problem. This booklet has now been revised and brought up to date; the new edition has been circulated since the end of the year.

\section{APPENDIX}

T A BLE A Number of cases (in all stages) dealt with for the first time at any centre ${ }^{\star}, 1950-68$, by sex

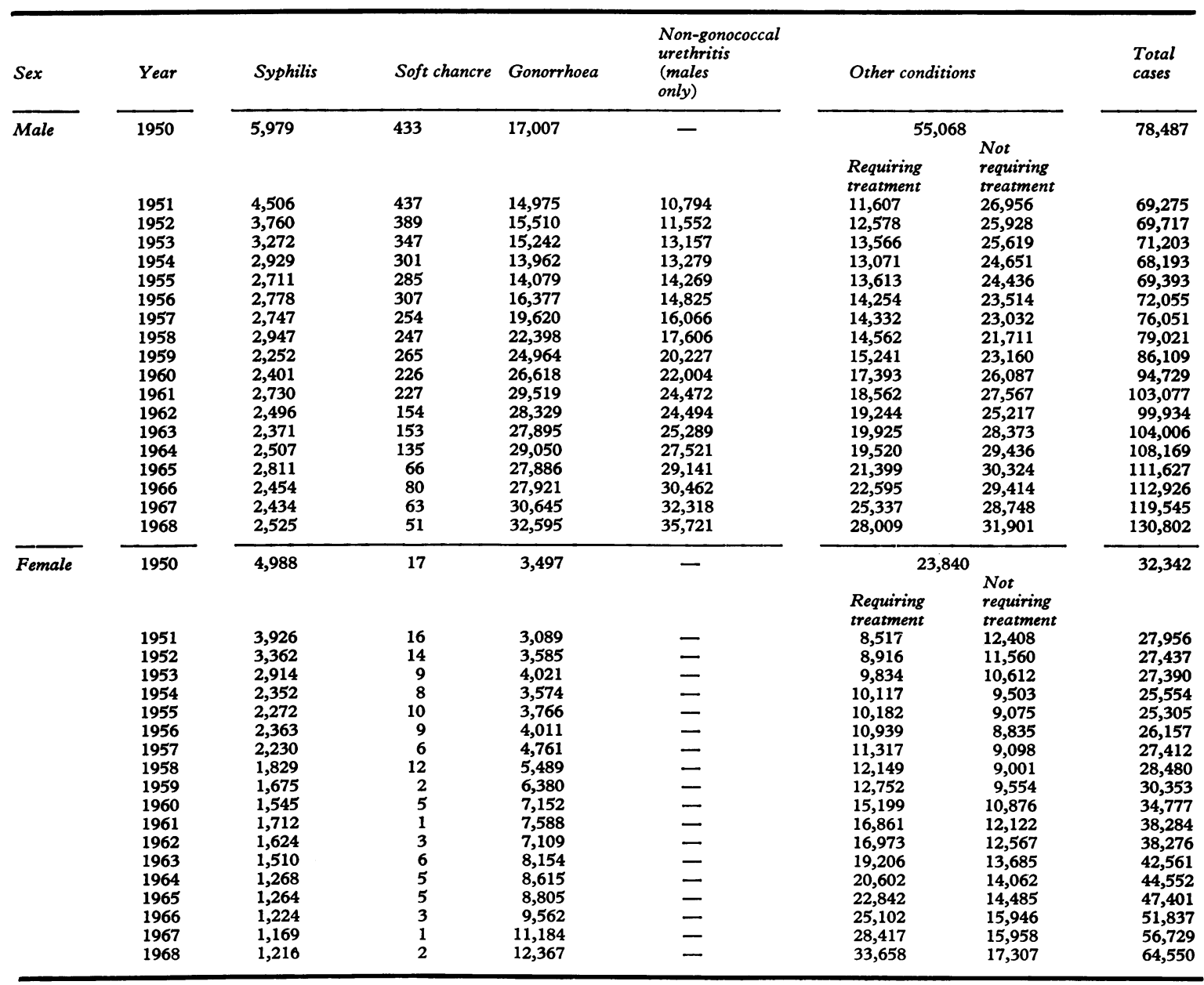


T A B LE B Cases of acquired syphilis in Table $A$ with infections of less than one year, 1950-68

\begin{tabular}{|c|c|c|c|c|}
\hline \multirow{2}{*}{ Year } & \multicolumn{2}{|c|}{ Number } & \multicolumn{2}{|c|}{ Percentage of Table $A$ cases } \\
\hline & Males & Females & Males & Females \\
\hline $\begin{array}{l}1950 \\
1951 \\
1952 \\
1953 \\
1954 \\
1955 \\
1956 \\
1957 \\
1958 \\
1959 \\
1960 \\
1961 \\
1962 \\
1963 \\
1964 \\
1965 \\
1966 \\
1967 \\
1968\end{array}$ & $\begin{array}{r}2,678 \\
1,498 \\
891 \\
755 \\
600 \\
609 \\
587 \\
555 \\
522 \\
564 \\
819 \\
965 \\
995 \\
1,135 \\
1,422 \\
1,734 \\
1,431 \\
1,378 \\
1,444\end{array}$ & $\begin{array}{r}1,465 \\
774 \\
462 \\
319 \\
208 \\
228 \\
257 \\
192 \\
182 \\
209 \\
175 \\
234 \\
229 \\
225 \\
315 \\
384 \\
388 \\
354 \\
382\end{array}$ & $\begin{array}{l}44 \cdot 8 \\
33 \cdot 2 \\
23 \cdot 7 \\
23 \cdot 0 \\
20 \cdot 5 \\
22 \cdot 5 \\
21 \cdot 1 \\
20 \cdot 2 \\
20 \cdot 9 \\
25 \cdot 0 \\
34 \cdot 1 \\
35 \cdot 3 \\
39 \cdot 9 \\
47 \cdot 9 \\
56 \cdot 7 \\
61 \cdot 9 \\
57 \cdot 3 \\
56 \cdot 6 \\
57 \cdot 2\end{array}$ & $\begin{array}{r}29.4 \\
19.7 \\
13.7 \\
10.9 \\
8.9 \\
10.0 \\
10.8 \\
8.6 \\
9.9 \\
12.5 \\
11.3 \\
13.6 \\
13.5 \\
16.9 \\
24.9 \\
30.4 \\
31.7 \\
30.3 \\
31.4\end{array}$ \\
\hline
\end{tabular}

T A B L E D Death rates per 1,000 livebirths, of infants under 1 year certified as due to congenital syphilis, 1913-68

\begin{tabular}{|c|c|c|c|c|c|c|c|}
\hline Year & Rate & Year & Rate & Year & Rate & Year & Rate \\
\hline 1913 & 1.46 & 1927 & 0.77 & 1941 & $0 \cdot 21$ & 1955 & - \\
\hline 1914 & 1.55 & 1928 & 0.71 & 1942 & 0.19 & 1956 & - \\
\hline 1915 & 1.44 & 1929 & 0.64 & 1943 & $0 \cdot 23$ & 1957 & - \\
\hline 1916 & 1.57 & 1930 & 0.55 & 1944 & 0.16 & 1958 & 0.004 \\
\hline 1917 & 2.03 & 1931 & 0.45 & 1945 & 0.15 & 1959 & 0.003 \\
\hline 1918 & 1.90 & 1932 & 0.42 & 1946 & 0.15 & 1960 & - \\
\hline 1919 & $1 \cdot 76$ & 1933 & 0.35 & 1947 & 0.09 & 1961 & - \\
\hline 1920 & 1.51 & 1934 & 0.30 & 1948 & 0.09 & 1962 & 0.001 \\
\hline 1921 & 1.43 & 1935 & $0 \cdot 26$ & 1949 & 0.08 & 1963 & - \\
\hline 1922 & $1 \cdot 12$ & 1936 & $0 \cdot 24$ & 1950 & 0.04 & 1964 & 0.001 \\
\hline 1923 & 1.05 & 1937 & 0.19 & 1951 & 0.03 & 1965 & 0.001 \\
\hline 1924 & 0.91 & 1938 & 0.18 & 1952 & 0.03 & 1966 & 0.001 \\
\hline 1925 & 0.82 & 1939 & $0 \cdot 17$ & 1953 & 0.01 & 1967 & 0.001 \\
\hline 1926 & 0.84 & 1940 & $0 \cdot 16$ & 1954 & 0.003 & 1968 & - \\
\hline
\end{tabular}

Rates for the years 1931-49 are according to the 1940 classification (5th Revision).

For 1913-30 the rates need to be multiplied by the conversion ratio 0.857 for approximate comparability.

For 1950-66 No. $020 \cdot 2$ in International List (7th Revision).
T A B L E C Cases of congenital syphilis dealt with for the first time at the treatment centres, 1950-68

\begin{tabular}{|c|c|c|c|c|c|}
\hline Year & $\begin{array}{l}\text { Under } \\
1 \text { year }\end{array}$ & $\begin{array}{l}1 \text { and under } \\
5 \text { years }\end{array}$ & $\begin{array}{l}5 \text { and under } \\
15 \text { years }\end{array}$ & $\begin{array}{l}15 \text { years } \\
\text { and over }\end{array}$ & Total \\
\hline 1950 & 227 & 141 & 203 & 652 & 1,223 \\
\hline 1951 & 156 & 89 & 198 & 684 & 1,127 \\
\hline 1952 & 110 & 101 & 191 & 547 & 949 \\
\hline 1953 & 95 & 77 & 152 & 520 & 844 \\
\hline 1954 & 48 & 41 & 119 & 478 & 686 \\
\hline 1955 & 41 & 30 & 114 & 459 & 644 \\
\hline 1956 & 36 & 31 & 82 & 441 & 590 \\
\hline 1957 & 27 & 26 & 77 & 427 & 557 \\
\hline 1958 & 17 & 15 & 65 & 340 & 437 \\
\hline 1959 & 20 & 19 & 29 & 304 & 372 \\
\hline 1960 & 18 & 10 & 38 & 323 & 389 \\
\hline 1961 & 23 & 4 & 21 & 292 & 340 \\
\hline 1962 & 11 & 8 & 12 & 287 & 318 \\
\hline 1963 & 16 & 5 & 16 & 325 & 362 \\
\hline 1964 & 8 & 3 & 11 & 236 & 258 \\
\hline 1965 & 17 & 5 & 5 & 248 & 275 \\
\hline 1966 & 12 & 5 & 9 & 236 & 262 \\
\hline 1967 & 15 & - & 5 & 196 & 216 \\
\hline 1968 & 14 & 4 & 7 & 229 & 254 \\
\hline
\end{tabular}

T A B L E E Deaths from general paralysis of the insane, tabes dorsalis, and aneurysm of the aorta, 1911-68

\begin{tabular}{|c|c|c|c|c|c|c|}
\hline \multirow{2}{*}{ Year } & \multicolumn{2}{|l|}{ G.P.I. } & \multicolumn{2}{|c|}{ Tabes dorsalis } & \multicolumn{2}{|c|}{ Aneurysm of aorta } \\
\hline & Males & Females & Males & Females & Males & Females \\
\hline $\begin{array}{l}1911-20 \\
1921-30 \\
1931-35 \\
1936-39\end{array}$ & $\begin{array}{r}1,697 \\
1,204 \\
819 \\
625\end{array}$ & $\begin{array}{l}383 \\
277 \\
240 \\
227\end{array}$ & $\begin{array}{l}592 \\
632 \\
566 \\
471\end{array}$ & $\begin{array}{l}106 \\
127 \\
125 \\
106\end{array}$ & $\begin{array}{r}838 \\
860 \\
969 \\
1,017\end{array}$ & $\begin{array}{l}208 \\
249 \\
393 \\
531\end{array}$ \\
\hline $\begin{array}{l}1940-44 \\
1945-49 \\
1950-54 \\
1955 \\
1956 \\
1957 \\
1958 \\
1959 \\
1960 \\
1961 \\
1962 \\
1963 \\
1964 \\
1965 \\
1966\end{array}$ & $\begin{array}{r}482 \\
258 \\
98 \\
84 \\
56 \\
48 \\
57 \\
62 \\
56 \\
37 \\
28 \\
39 \\
24 \\
23 \\
39\end{array}$ & $\begin{array}{r}167 \\
101 \\
42 \\
36 \\
28 \\
20 \\
28 \\
27 \\
22 \\
17 \\
16 \\
10 \\
12 \\
16 \\
10\end{array}$ & $\begin{array}{r}270 \\
157 \\
93 \\
53 \\
66 \\
53 \\
41 \\
50 \\
44 \\
41 \\
23 \\
29 \\
15 \\
24 \\
18\end{array}$ & $\begin{array}{r}71 \\
41 \\
27 \\
24 \\
15 \\
22 \\
16 \\
22 \\
17 \\
19 \\
6 \\
16 \\
12 \\
9 \\
7\end{array}$ & $\begin{array}{l}367 \\
381 \\
336 \\
332 \\
329 \\
358 \\
306 \\
295 \\
312 \\
286 \\
303 \\
277 \\
326 \\
354 \\
343\end{array}$ & $\begin{array}{l}124 \\
130 \\
166 \\
173 \\
171 \\
183 \\
219 \\
190 \\
186 \\
194 \\
198 \\
209 \\
195 \\
260 \\
246\end{array}$ \\
\hline $\begin{array}{l}1967^{\star} \\
1968^{\star}\end{array}$ & $\begin{array}{l}23 \\
16\end{array}$ & $\begin{array}{l}4 \\
9\end{array}$ & $\begin{array}{l}14 \\
14\end{array}$ & $\begin{array}{r}12 \\
6\end{array}$ & $\begin{array}{l}26 t \\
15 t\end{array}$ & $\begin{array}{l}45 t \\
29 t\end{array}$ \\
\hline
\end{tabular}

*Deaths in 1967 and 1968 are based on 8th Revision International Classification of Diseases.

†Deaths from Aneurysm of aorta specified as syphilitic only.

The average for the years 1911-39 are based on the 4th Revision of the International List. Figures for the years 1940-66 are according to the 7th Revision.

Non-civilian deaths are excluded from September 3 1939, for males and from June 11941 ,for females, to December 311949. 
T A B E F New cases of primary and secondary syphilis and early syphilis and post-pubertal gonorrhoea per 100,000 population, by age group and sex Hospital clinics, England and Wales, 1968

\begin{tabular}{|c|c|c|c|c|c|}
\hline Disease & $\begin{array}{l}\text { Age group } \\
\text { (yrs) }\end{array}$ & \multicolumn{2}{|l|}{1967} & \multicolumn{2}{|l|}{1968} \\
\hline Syphilis Early & All ages* & $5 \cdot 85$ & $1 \cdot 43$ & $6 \cdot 11$ & 1.53 \\
\hline Primary and secondary & $\begin{array}{l}\text { All ages } \\
\text { under } 16 \\
16 \text { and } 17 \\
18 \text { and } 19 \\
20-24 \\
25 \text { and over }\end{array}$ & $\begin{array}{r}4 \cdot 56 \\
0 \cdot 03 \\
2 \cdot 85 \\
9 \cdot 33 \\
12 \cdot 58 \\
5 \cdot 31\end{array}$ & $\begin{array}{l}0.99 \\
0.03 \\
2.39 \\
3.45 \\
4.31 \\
0.79\end{array}$ & $\begin{array}{r}4 \cdot 59 \\
0 \cdot 05 \\
2 \cdot 37 \\
7 \cdot 60 \\
15 \cdot 02 \\
5 \cdot 15\end{array}$ & $\begin{array}{l}0 \cdot 94 \\
0 \cdot 03 \\
2 \cdot 77 \\
4 \cdot 78 \\
3 \cdot 70 \\
0 \cdot 71\end{array}$ \\
\hline Congenital & $\begin{array}{l}\text { All ages } \\
\text { under } 1 \text { year } \\
1-4 \\
5-14 \\
15 \text { and over }\end{array}$ & $\begin{array}{l}0.39 \\
1.65 \\
0 . \overline{08} \\
0.45\end{array}$ & $\begin{array}{l}0.50 \\
1.99 \\
0 . \overline{06} \\
0.59\end{array}$ & $\begin{array}{l}0.42 \\
1.45 \\
0.06 \\
0.08 \\
0.50\end{array}$ & $\begin{array}{l}0.62 \\
2.03 \\
0 \cdot 18 \\
0 \cdot 11 \\
0.72\end{array}$ \\
\hline Gonorrhoea, post-pubertal & $\begin{array}{l}\text { All ages } \\
\text { under } 16 \\
16 \text { and } 17 \\
18 \text { and } 19 \\
20-24 \\
25 \text { and over }\end{array}$ & $\begin{array}{r}130.00 \\
0.67 \\
82.89 \\
297.51 \\
526.97 \\
128.58\end{array}$ & \begin{tabular}{r|}
$44 \cdot 63$ \\
$3 \cdot 15$ \\
154.58 \\
$270 \cdot 16$ \\
$222 \cdot 98$ \\
$24 \cdot 57$
\end{tabular} & $\begin{array}{r}137 \cdot 90 \\
1 \cdot 22 \\
101 \cdot 27 \\
349 \cdot 23 \\
554 \cdot 54 \\
133 \cdot 71\end{array}$ & \begin{tabular}{|r|}
$49 \cdot 22$ \\
$4 \cdot 03$ \\
$186 \cdot 27$ \\
303.93 \\
$240 \cdot 52$ \\
$26 \cdot 78$
\end{tabular} \\
\hline
\end{tabular}

^Primary, secondary, and latent in the first year of infection.

TAB L E G Nerw cases of other conditions per 100,000 population, all ages, by sex Hospital clinics, England and Wales

Other conditions

Total

(I) Chancroid

(II) Lymphogranuloma venereum

(III) Granuloma Inguinale

(IV) Non-gonococcal urethritis

(V) Non-gonococcal urethritis with arthritis

Total of (IV) and (V)

\begin{tabular}{crrr}
\cline { 4 - 4 } (VI) Late or latent treponematoses pre- & & \\
$\begin{array}{c}\text { sumed to be non-syphilitic } \\
\text { (VII) Other conditions requiring treat- }\end{array}$ & 2.18 & 1.75 \\
ment within the centre & 118.53 & 134.83 \\
(VIII) Conditions requiring no treatment & & 135.00 & 69.33 \\
within the centre & 0.91 & 0.79 \\
\hline
\end{tabular}

\begin{tabular}{rc}
1968 & \\
\hline Male & Female \\
\hline 408.27 & 206.72 \\
0.22 & 0.01 \\
0.22 & 0.01 \\
0.04 & $\begin{array}{c}0.00 \\
(=1 \text { case only }\end{array}$ \\
\hline 149.91 & - \\
1.26 & - \\
151.17 & - \\
\hline 2.18 & 1.75 \\
118.53 & 134.83 \\
135.00 & 69.33 \\
0.91 & 0.79
\end{tabular}

